\title{
Effect of Current Density and Contact Time of Electro-Coagulation on the Characteristics of Activated Sludge and Membrane Filtration
}

\author{
Kyeong-Rae Kim ${ }^{\circledR} \cdot$ In-Soung Chang ${ }^{\dagger}$
}

Department of Environmental Engineering, Hoseo University

(Received April 7, 2021; Revised May 24, 2021; Accepted June 1, 2021)

Objectives: The effect of current density and contact time of electro-coagulation on membrane fouling was investigated. In order to elucidate the reason why the membrane fouling was reduced by electro-coagulation, the changes in the characteristics of activated sludge were examined before and after electro-coagulation.

Methods: A series of electro-coagulation of activated sludge suspensions was carried out with current density of $2.5,6,12,24 \mathrm{~A} / \mathrm{m}^{2}$ for $0,2,6,12$ hours. After membrane filtrations of the activated sludge suspensions, the membrane fouling was compared before and after the electro-coagulation. Characteristic changes in the activated sludge were also analyzed quantitatively.

Results and Discussion: Total fouling resistances $\left(\mathrm{R}_{t}\right)$ of the electro-coagulated activated sludge decreased as current density and contact time increased. For example, $\mathrm{R}_{\mathrm{t}}$ decreased $15 \%, 63 \%$ and $86 \%$ under the condition of current density of $24 \mathrm{~A} / \mathrm{m}^{2}$ and 2, 6, 12 hours of contact time. Particularly, three activated sludge suspensions having very different initial MLSS concentrations showed a similar reduction of $\mathrm{R}_{\mathrm{t}}$, indicating that the membrane fouling was reduced not dominantly by particulates but by soluble foulants. The MLSS increased as current density increased, but MLVSS had not changed accordingly, which means that inorganic solids such as $\mathrm{Al}(\mathrm{OH})_{3}$ and $\mathrm{AlPO}_{4}$ produced during electro-coagulation were the main reasons for the increased MLSS concentration. These solids could play a key role in the reduction of membrane fouling by means of a dynamic membrane. As current density increased, the EPS (extracellular polymeric substances) and soluble COD concentration were reduced, which led to the reduction of membrane fouling. Soluble TN and TP were not significantly changed after electro-coagulation.

Conclusions: The fouling materials, particularly, EPS and soluble COD decreased as current density and contact time increased, which played a key role in the reduction of membrane fouling. In addition, the insoluble solids produced during the electro-coagulation would act as a dynamic membrane, which led to fouling reduction.

Keywords: Current Density, Electro-Coagulation, Extracellular Polymeric Substances, Membrane Bio-Reactor, Membrane Fouling

The Korean text of this paper can be translated into multiple languages on the website of http:/jksee.or.kr through Google Translator. 


\section{연구논문}

\section{전기응집의 전류밀도와 접촉시간이 활성슬러지와 막 여과 특성에 미치는 영향}

\section{김경래 ${ }^{\circledR}$ - 장인성 ${ }^{+\oplus}$}

호서대학교 환경공학과

목적 : 전기응집(electro-coagulation) 공정에서 전류밀도와 접촉시간이 막 오염에 미치는 영향을 살펴보았다. 또 한, 전기응집이 활성슬러지 특성에 미치는 영향을 연구하여 막 오염 저감과 어떤 상관관계가 있는지 해석하고자 하였다.

방법: 활성슬러지 현탁액에 $2.5,6,12,24 \mathrm{~A} / \mathrm{m}^{2}$ 범위의 전류밀도와 $0,2,6,12$ 시간의 접촉시간으로 전기응집을 수 행하였다. 전기응집을 하지 않은 대조군과 전기응집을 수행한 활성슬러지 현탁액을 막 여과한 후, 막 오염 정도를 저항값으로 산출하였다. 또한, 전기응집 전후의 활성슬러지 현탁액의 특성을 정량분석하였다.

결과 및 토의: 전기응집의 접촉시간과 전류밀도가 증가할수록 총오염저항 $\left(\mathrm{R}_{\mathrm{t}}\right)$ 이 감소하였다. 전류밀도 $24 \mathrm{~A} / \mathrm{m}^{2}$ 에서 접촉시간 $2,6,12$ 시간일 때 총오염저항은 대조군에 비해 각각 $15,63,86 \%$ 감소하였다. MLSS 농도가 다른 세 종류 의 활성슬러지 혼합액을 여과하였음에도 불구하고 총오염저항 감소율은 거의 유사하였다. 이는 전기응집이 MLSS 로 대표되는 입자성 막 오염 물질보다는 용존성 막 오염 물질의 제거 기작에 효과적으로 작용하였음을 시사한다. 전류밀도가 증가할수록 MLSS 농도가 증가하였지만 MLVSS는 큰 변화가 없었다. 즉, 응집과정에서 발생하는 무기 염, $\mathrm{Al}(\mathrm{OH})_{3}$ 과 $\mathrm{AlPO}_{4}$ 에 의해 무기성 고형물 성분이 증가하여 MLSS가 증가하였으며, 이렇게 생성되는 불용성 무 기물이 동적 막 역할을 하여 막 오염 감소의 주요 원인으로 작용하였다. 막 오염에 큰 영향을 미치는 세포외고분자 물질(EPS) 농도와 용존성-COD는 전류밀도가 증가할수록 감소하는 경향을 보였다. 반면, 용존성-TN과 용존성-TP 는 전기응집에 의한 막 오염 감소와는 상관관계가 크지 않은 것으로 나타났다.

결론: 전기응집의 전류밀도와 접촉시간이 증가할수록 활성슬러지 현탁액에 존재하는 막 오염 물질 특히, EPS 및 용존성-COD 등이 감소하여 막 오염이 감소하였다. 동시에 전기응집으로 인해 발생하는 불용성 무기염이 동적 막 기능을 통해 막 오염이 감소하였다.

주제어: 막 오염, 생물막반응기, 세포외 고분자 물질, 전기응집, 전류밀도

\section{1. 서론}

MBR (Membrane bio-reactor) 공정은 전통적인 표준 활성슬 러지 공법의 2 차 침전조를 정밀여과 또는 한외여과와 같은 분 리막 시스템으로 대체한 것이다. 막 여과로 인해 완벽한 고/액 분리가 가능하여 $10,000 ~ 15,000 \mathrm{mg} / \mathrm{L}$ 정도의 높은 MLSS (Mixed liquors of suspended solids) 농도로 포기조 운영이 가 능하여 안정적인 유출수질을 확보할 수 있고, SRT (Solids retention time)를 높게 유지할 수 있어 잉여슬러지를 적게 발 생시키는 장점이 있다. ${ }^{1)}$ 이런 이유로 MBR은 하수의 고도처리 또는 재이용 공정 등에 활발히 사용되고 있다. ${ }^{2,3)}$ 그러나 $\mathrm{MBR}$ 공정은 여러 가지 장점에도 불구하고 막 분리 공정에서 필연적 으로 발생하는 막 오염 때문에 그 활용이 제한받고 있다.
따라서 막 오염 제어를 위해 다양한 물리, 화학, 생물학적 막 오염 제어방법이 연구, 개발되고 있다. 대표적인 물리적 세정법은 막 표면으로 조대포기(coarse aeration)를 수행하여 오염된 케이크 층을 제거하거나, 여과수(또는 세정수)를 여과 반대 방향으로 흘려서 막 오염 물질을 막 표면에서 탈리시키 는 역세척이 광범위하게 시행되고 있는 방법이다. ${ }^{4)}$ 그러나 여과가 진행될수록 막과 오염물질 사이에 비가역적 막 오염 이 발생하기 때문에 초기 플럭스를 회복하기 위하여 차아염 소산염과 같은 산화제를 이용한 화학 세정을 물리적 세정법 과 함께 사용한다. ${ }^{5,6)}$ 미생물 세포 간의 의사소통을 차단하여 생물 막을 형성하는 능력을 저해하여 막 표면에 누적되는 케 이크 층 발생을 억제하는 정족수감지저해(quorum sensing and quenching)와 같은 생물학적 방법 등도 활발히 연구되고 있으 
나 아직 실용화되지는 못하고 있다. ${ }^{7-9)}$

최근에는 화학약품인 응집제를 사용하지 않고 응집 효과를 얻을 수 있는 전기응집(electro-coagulation) 기술을 이용한 수 처리 공정에 대한 관심이 높아지고 있다. ${ }^{10-12)}$ 전기응집은 수 중에 침지된 전극에 전류를 흘려서 양이온을 용출하게 하여 응집을 유도하는 기술을 일컫는다. 용출된 양이온은 일반적인 응집과정과 동일한 메카니즘으로 수중의 콜로이드성 물질을 응집하여 막 오염을 완화하는 역할을 한다. ${ }^{13)}$ 이러한 전기응 집 기술을 $\mathrm{MBR}$ 에 접목시켜 막 오염 제어에 효과가 있음을 증명하는 연구들이 속속 보고되고 있다. ${ }^{14,15)}$ 전기응집이 $\mathrm{MBR}$ 의 막 오염에 중요한 역할을 하는 콜로이드성 물질 및 용존성 물질을 응집시키거나 슬러지의 탈수 효과 등으로 인해 막 오 염을 완화할 수 있는 것으로 보고되고 있다. ${ }^{16-20)}$ 한편 화학약 품을 이용한 응집 공정은 전기응집 공정에 비해 초기투자 비 용이 적은 반면에, 화학약품의 사용에 관한 안전 규제가 계속 증가하고 있는 현 추세에서 화학약품의 사용에 소요되는 유지 관리 비용이 큰 것으로 인식되고 있다. 전기응집 공정은 전원 공급장치와 전극 등에 소요되는 초기투자비용이 부담되지만, 별도의 약품 사용이 없기 때문에 안전 규제에서 비교적 자유 로울 수 있는 장점이 있다.

그러나 MBR에 전기응집을 결합한 공정의 운전조건을 탐색 하거나 전기응집이 활성슬러지의 생물학적 특성을 어떻게 변 화시키는지에 대한 연구는 미흡한 편이다. 막 오염에 직접 관 여하는 활성슬러지 미생물의 특성들은 매우 다양하고 복잡하 기 때문에 이에 관한 구체적인 연구가 필요하다.

따라서 본 연구에서는 전기응집이 효과적으로 $\mathrm{MBR}$ 의 막 오염을 제어하기 위해서 반드시 필요한 정보 즉, 전기응집이 활성슬러지 특성에 어떠한 영향을 미치는지에 대한 연구를 수행하였고, 그 영향이 막 오염 저감과 어떤 상관관계가 있는 지 해석하고자 하였다.

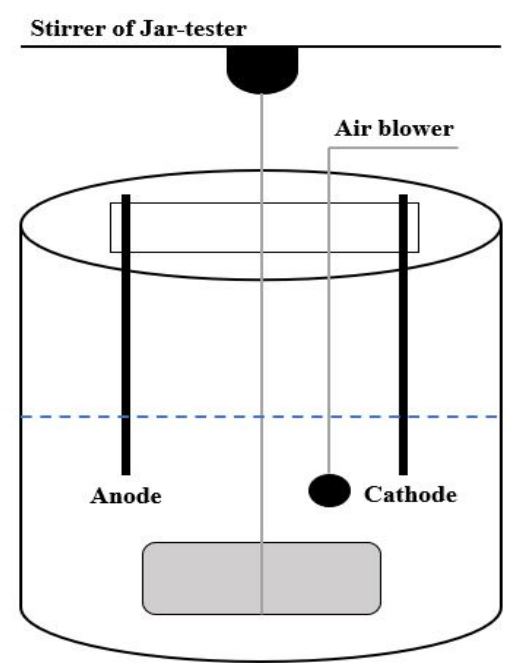

Table 1. Cultivation conditions of the reactor for acclimation of activated sludge.

\begin{tabular}{cccc} 
Parameters & \multicolumn{3}{c}{ Values } \\
F/M ratio, kgCOD/kgMLSS & \multicolumn{3}{c}{$0.35 \sim 0.85$} \\
\hline MLSS, mg/L & 3,950 & 6,200 & 8,150 \\
\hline HRT (hydraulic retention time), hr & $12 \sim 12.8$ & 10 \\
\hline SRT (solids retention time), day & 6 & 8 & \\
\hline Working volume, $\mathrm{L}$ & \multicolumn{3}{c}{16} \\
\hline $\mathrm{pH}$ & $20 \pm 5$ & \\
\hline Temperature, ${ }^{\circ} \mathrm{C}$ & &
\end{tabular}

\section{2. 실험 장치 및 방법}

\section{1. 활성슬러지 배양}

$\mathrm{A}$ 시 환경 사업소 포기조의 활성슬러지 혼합액을 채취하여 실험실의 $16 \mathrm{~L}$ 원통형 아크릴 반응조로 운송한 후, 연속회분 식반응기(sequenced batch reactor) 형태로 운용하면서 활성슬 러지를 배양하였다. 정상상태에 도달할 때까지 합성폐수로 순 응시킨 후 막 여과 실험에 사용하였다. 합성폐수는 Glucose $2,000 \mathrm{mg} / \mathrm{L}$, Peptone $300 \mathrm{mg} / \mathrm{L}$, Yeast extract $800 \mathrm{mg} / \mathrm{L}$, $\left(\mathrm{NH}_{4}\right)_{2} \mathrm{SO}_{4} 200 \mathrm{mg} / \mathrm{L}, \mathrm{KH}_{2} \mathrm{PO}_{4} 50 \mathrm{mg} / \mathrm{L}, \mathrm{MgSO}_{4} \cdot 7 \mathrm{H}_{2} \mathrm{O} 70$ $\mathrm{mg} / \mathrm{L}, \mathrm{MnSO}_{4} \cdot 4 \sim 5 \mathrm{H}_{2} \mathrm{O} 15 \mathrm{mg} / \mathrm{L}, \mathrm{CaCl}_{2} \cdot 2 \mathrm{H}_{2} \mathrm{O} 120 \mathrm{mg} / \mathrm{L}$, $\mathrm{NaHCO}_{3} 1,000 \mathrm{mg} / \mathrm{L}$ 농도로 모 용액을 제조하여 이를 희석한 후 사용하였다. 활성슬러지 배양조건은 Table1에 요약하였다.

\section{2. 전기응집}

전기응집을 위해 최대전압 $50 \mathrm{~V}$, 최대전류 $20 \mathrm{~A}$ 까지 조절 가능한 직류전원 공급장치(UDP-5020, Unicon, Korea)를 사용 하였다. 전기응집 실험이 수행되는 응집 반응조는 아크릴 재 질의 $1 \mathrm{~L}$ 반응기(내경 $110 \mathrm{~mm}$, 외경 $120 \mathrm{~mm}$, 높이 $155 \mathrm{~mm}$ ) 로 제작되었으며, 반응기의 덮개는 전극을 고정할 수 있는 홈

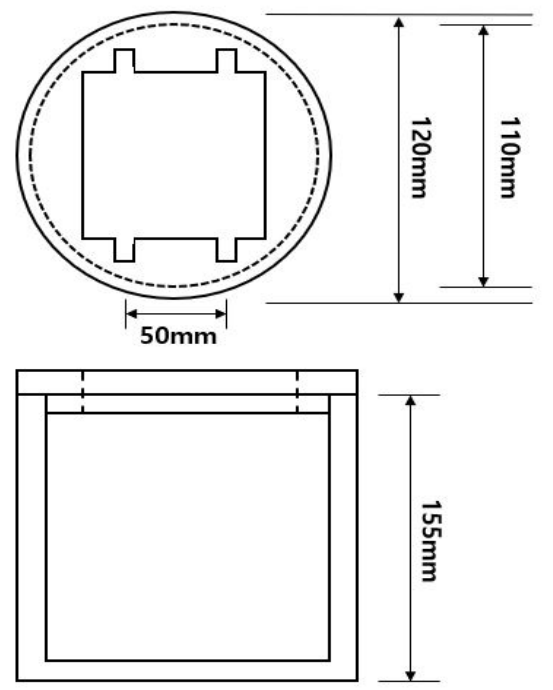

Fig. 1. Schematic diagram of the electro-coagulation reactor. 
Table 2. Operating condition of the batch typed electro-coagulation.

\begin{tabular}{|c|c|c|c|c|c|}
\hline Parameter & \multicolumn{4}{|c|}{ Value } & Unit \\
\hline Activated sludge with different MLSS & 3,950 & \multicolumn{2}{|c|}{6,200} & 8,150 & $\mathrm{mg} / \mathrm{l}$ \\
\hline Reactor working volume & \multicolumn{4}{|c|}{1} & L \\
\hline Distance between electrodes & \multicolumn{4}{|c|}{5} & $\mathrm{~cm}$ \\
\hline Submerged electrode area & \multicolumn{4}{|c|}{33.5} & $\mathrm{~cm}^{2}$ \\
\hline Current density & 2.5 & 6 & 12 & 24 & $\mathrm{~A} / \mathrm{m}^{2}$ \\
\hline Contact time & $0,2,6,12$ & $0,2,6,12$ & $0,2,6,12$ & $0,2,6,12$ & $\mathrm{hr}$ \\
\hline Stirring speed & \multicolumn{4}{|c|}{100} & rpm \\
\hline Air supply & \multicolumn{4}{|c|}{0.5} & $\mathrm{~L} / \mathrm{min}$ \\
\hline
\end{tabular}

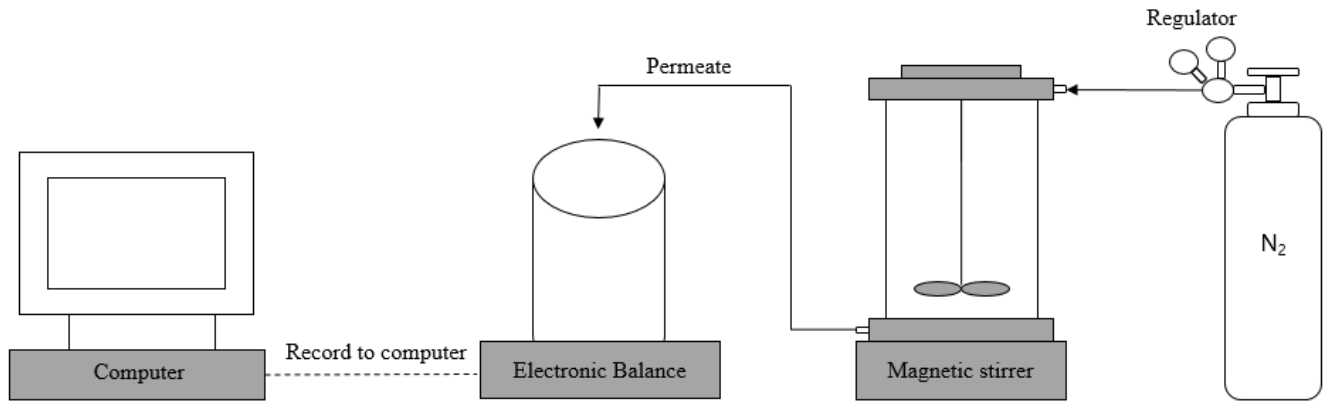

Fig. 2. Schematic of the stirred cell type of membrane filtration system.

과 자테스터의 교반기 부분이 들어갈 수 있도록 제작되었다

(Fig. 1). 반응기 내부에 고정된 전극은 $50 \times 130 \mathrm{~mm}$ 크기의 알루미늄 판으로 제작하였다.

활성슬러지 혼합액을 전기응집 반응기에 넣고 전극 간 거리 를 $50 \mathrm{~mm}$ 로 고정하고 덮개를 닫은 후 원활한 혼합을 위해 자-테스터로 교반하면서 일련의 회분식 전기응집을 수행했다.

전기응집법에 적용되는 일반적인 전류밀도(current density) 는 2 30 A/m $\mathrm{m}^{2}$ 임을 감안하여, 본 연구에서는 $2.5,6,12,24$ $\mathrm{A} / \mathrm{m}^{2}$ 로 전류밀도값을 설정하였다. 각각의 전류밀도 조건에서 접촉시간을 $0,2,6,12$ 시간으로 변화시켜 가며 전기응집을 수행하였으며 전류밀도를 인가하지 않은 즉, 접촉시간 0시간 일 때의 데이터를 대조군으로 하였다. 자세한 전기응집 운전 조건을 Table 2에 제시하였다.

\section{3. 분석방법}

전기응집이 활성슬러지 특성변화에 미치는 영향을 파악하기 위해 전기응집 전·후의 활성슬러지 특성 즉, MLSS, MLVSS, 용존성-COD, 용존성-TN, 용존성-TP 및 세포외고분자물질 (EPS, Extracellular polymeric substances)을 분석하였다. EPS를 제외한 나머지 분석 항목은 Standard Methods ${ }^{21)}$ 에 준 하여 분석하였다. EPS는 열처리법 ${ }^{22)}$ 을 통하여 soluble-EPS와 bound-EPS를 분리, 추출하여 분석하였다.

$\mathrm{EPS}$ 의 주성분인 단백질과 다당류를 각각 분석하였다. 단백 질 성분은 BSA (Bovine serum albumin)를 표준물질로 하여 Lowry 법 ${ }^{23)}$ 으로 분석하였고, 다당류 성분은 glucose를 표준물
질로 하여 Phenol-sulfuric acid 법 ${ }^{24)}$ 으로 분석하였다. 용존성 -COD, 용존성-TN, 용존성-TP 분석에 사용된 시료는 여과지 로 여과한 여액을 분광광도계(DR/4000 U, Hach Inc., USA)로 분석하였다.

\section{4. 막 오염 정량화}

활성슬러지의 막 여과 성능을 파악하기 위해 회분식 여과셀 (Amicon 8200, Amicon, USA)을 이용하여 막 여과를 수행하 였다(Fig. 2). 여과에 사용된 분리막은 분획분자량이 $30 \mathrm{kD}$ 인 디스크형 한외여과막(PLTK06210, Millipore, USA)을 이용하 였다. 셀 내부의 압력은 질소 실린더를 이용하여 $2 \mathrm{~atm}$ 으로 조절하였다. 전자저울 상부에 위치한 용기에 막을 투과한 여 과수를 수집한 후, 컴퓨터와 전자저울을 연결하여 투과수의 질량 변화를 단위 시간마다 측정하여 막 여과 자료를 수집하 였다.

수집된 여과 자료를 식 (1)과 같은 직렬여과저항(Resistancein-series) 모델 ${ }^{25}$ 에 적용하여 3 가지 저항, $\mathrm{R}_{\mathrm{m}}$ (Intrinsic membrane resistance), $\mathrm{R}_{\mathrm{f}}$ (Internal pore fouling resistance), $\mathrm{R}_{\mathrm{c}}$ (Cake layer resistance)를 각각 계산하였다.

$\mathbf{J}=\frac{\mathrm{TMP}}{\mu \cdot\left(\mathrm{R}_{\mathrm{m}}+\mathrm{R}_{\mathrm{c}}+\mathrm{R}_{\mathrm{f}}\right)}$

$\mathrm{J}=$ Flux,$\mu=$ viscosity of activated sludge suspension

TMP: Trans-Membrane Pressure 
막 여과 실험은 i) 순수여과, ii) 활성슬러지 여과, iii) 분리막 세척 후 순수여과 순으로 진행하였다. 즉, i) 초순수 $(>18.3 \mathrm{M} \Omega)$ 를 분리막으로 여과하여 $\mathrm{J}_{\mathrm{iw}}$ (초기 물 플럭스)를 구한 후, ii) 활성슬러지를 여과하여 $\mathrm{J}$ (활성슬러지 플럭스) 자료를 얻는다. 이후 분리막을 여과셀로부터 분리하고 순수로 세척하여 막 표면의 케이크 층을 제거한다. iii) 다시 초순수 여과를 수행하 여 $\mathrm{J}_{\mathrm{fw}}$ (최종 물 플럭스)를 구한다. 회분식 교반셀을 통한 여과 실험 후 얻은 플럭스 자료 $\left(\mathrm{J}_{\mathrm{iw}}, \mathrm{J}, \mathrm{J}_{\mathrm{fw}}\right)$ 를 다음 식 (2), (3), (4)에 대입하여 각 저항값 $\left(\mathrm{R}_{\mathrm{c}}, \mathrm{R}_{\mathrm{c}}, \mathrm{R}_{\mathrm{f}}\right)$ 을 계산하였다.

$$
\begin{aligned}
& \mathrm{R}_{\mathrm{m}}=\frac{\Delta \mathrm{P}}{\mu \cdot \mathrm{J}_{\mathrm{iw}}} \\
& \mathrm{R}_{\mathrm{f}}=\frac{\Delta \mathrm{P}}{\mu \cdot \mathrm{J}_{\mathrm{fw}}}-\mathrm{R}_{\mathrm{m}} \\
& \mathrm{R}_{\mathrm{c}}=\frac{\Delta \mathrm{P}}{\mu \cdot \mathrm{J}_{\mathrm{fw}}}-\left(\mathrm{R}_{\mathrm{m}}+\mathrm{R}_{\mathrm{f}}\right)
\end{aligned}
$$

\section{3. 결과 및 고찰}

\section{1. 전기응집 조건에 따른 여과 성능 비교}

MLSS 농도가 서로 다른 활성슬러지 혼합액에 전류밀도와 접촉시간을 변화시켜 가며 전기응집을 수행하였다. 이후 활성 슬러지 혼합액을 막 여과하여 얻은 여과 자료를 이용하여 각 저항값을 계산하였다. 막 오염의 결과로 발생하는 분리막 표 면의 케이크층저항 $\left(\mathrm{R}_{\mathrm{c}}\right)$ 과 막 공극 내 오염저항 $\left(\mathrm{R}_{\mathrm{f}}\right)$ 을 더한 값 을 총오염저항(total fouling resistance), $\mathrm{R}_{\mathrm{t}}\left(=\mathrm{R}_{\mathrm{c}}+\mathrm{R}_{\mathrm{f}}\right)$ 로 정의하 고 이를 분리막 오염의 지표로 삼았다.

인가된 전류밀도별로 시간에 따라 감소한 총오염저항 비율을 Fig. 3 에 나타내었다. 그래프의 $\mathrm{y}$ 축은 $\left(\mathrm{R}_{\mathrm{c}}+\mathrm{R}_{\mathrm{f}}\right)_{\mathrm{EC}} /$ $\left(\mathrm{R}_{\mathrm{c}}+\mathrm{R}_{\mathrm{f}}\right)_{\text {Ccontrol }} \times 100(\%)$ 이다. 전기응집으로 인해 감소하는 막 오염 저감 정도를 표시하기 위해 $\left(\mathrm{R}_{\mathrm{c}}+\mathrm{R}_{\mathrm{f}}\right)_{\mathrm{EC}} /\left(\mathrm{R}_{\mathrm{c}}+\mathrm{R}_{\mathrm{f}}\right)_{\mathrm{Control}}$ 를 사용하였다. 즉, 전기응집을 가하지 않은 대조군의 총오염저항,

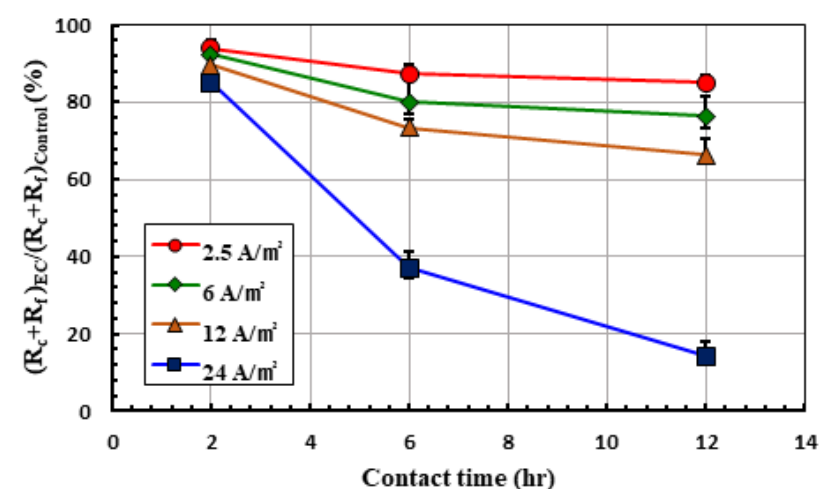

Fig. 3. Reduction of total fouling resistance $\left(R_{t}\right)$ as a function of contact time and current density (MLSS= 3,950 $8,500 \mathrm{mg} / \mathrm{L})$.
$\left(\mathrm{R}_{\mathrm{c}}+\mathrm{R}_{\mathrm{f}}\right)_{\mathrm{Control}}$ 과 전기응집 이후 감소한 총오염저항, $\left(\mathrm{R}_{\mathrm{c}}+\mathrm{R}_{\mathrm{f}}\right)_{\mathrm{EC}}$ 의 비율을 감소한 막 오염 지표로 사용하였다.

접촉시간과 전류밀도가 증가할수록 총오염저항 $\left(\mathrm{R}_{\mathrm{t}}\right)$ 은 감소 하였다. 전류밀도가 $24 \mathrm{~A} / \mathrm{m}^{2}$ 이었을 경우 총오염저항은 접촉 시간 $2,6,12$ 시간일 때, 대조군에 비해 각각 $15,63,86 \%$ 감소 하였다. 반면, 전류밀도가 제일 작은 $2.5 \mathrm{~A} / \mathrm{m}^{2}$ 에서는 8,20 , $24 \%$ 정도만 감소하였다.

Hua 등 $(2015)^{26)}$ 은 MLSS 농도가 $4,440 \mathrm{mg} / \mathrm{L}$ 정도인 활성슬 러지를 $20 \mathrm{~A} / \mathrm{m}^{2}$ 의 전류밀도를 인가하여 총오염저항이 약 $53 \%$ 감소하는 결과를 보고하였다. 또한, Liu 등(2012) $)^{27)}$ 은 초 기 MLSS 농도가 4,252 mg/L인 활성슬러지를 $5 \mathrm{~mA}$ 의 전류를 인가하여 총 오염저항이 약 $82.6 \%$ 감소하는 결과를 보고하였 다. 그러나 막 오염에 영향을 미치는 가장 큰 인자인 활성슬러 지의 특성(이를테면 SRT, MLSS 및 $\mathrm{f} / \mathrm{m}$ 비 등)과 사용한 분리 막의 특성(세공 크기, 소수성 및 공극률 등)이 본 연구와 동일 하지 않기 때문에 본 연구의 결과와 일률적으로 비교하는 것은 다소 제한적일 수밖에 없다. 그러나 위에서 얻은 총오 염저항 감소 정도는 여러 문헌에서 보고된 전기응집으로 얻 게 되는 막 오염 저감 정도와 유사한 범위를 보이는 것으로 판단된다.

본 연구에서는 MLSS 농도를 3,950, 6,200, 8,150 mg/L로 다르게 하여 전기응집을 수행하였다. 그러나 MLSS 농도는 전기응집에 의한 총오염저항 감소에 큰 영향을 주지 않았다. 막 오염에 영향을 미치는 다른 모든 조건이 동일하다면, 활성 슬러지 혼합액의 MLSS 농도가 증가할수록 막 오염이 상승하 는 것이 일반적이다. 즉, MLSS 농도가 $3,950 \mathrm{mg} / \mathrm{L}$ 에서 6,200 $\mathrm{mg} / \mathrm{L}$ 그리고 $8,150 \mathrm{mg} / \mathrm{L}$ 로 증가하면 총오염저항 $\left(\mathrm{R}_{\mathrm{t}}\right)$ 자체는 $3,950 \mathrm{mg} / \mathrm{L}$ 인 경우보다 증가하였다. 그러나 MLSS 농도가 서 로 다른 세 종류의 활성슬러지 혼합액을 여과하였음에도 불구 하고 총오염저항 감소율은 거의 유사하였다. 즉, MLSS 농도 가 $3,950 \mathrm{mg} / \mathrm{L}$ 인 활성슬러지를 $24 \mathrm{~A} / \mathrm{m}^{2}$ 의 전류밀도에서 접촉 시간 $2,6,12$ 시간의 전기응집을 수행하면, 총오염저항은 각각 $14 \%, 68 \%, 89 \%$ 감소하였다. 그러나 MLSS 농도가 8,150 $\mathrm{mg} / \mathrm{L}$ 로 약 2 배 이상 증가하면 총오염저항 자체는 증가하였다. 그러나 총오염저항 감소율은 $11 \%, 60 \%, 82 \%$ 감소하여 3,950 $\mathrm{mg} / \mathrm{L}$ 인 경우와 비교하여도 큰 차이가 나지 않는 것을 알 수 있다. 이는 전기응집이 MLSS로 대표되는 입자성 막 오염 물 질보다는 용존성 막 오염 물질의 제거 기작에 효과적으로 작 용함을 시사한다.

\section{2. 전기응집 조건에 따른 $\left.A\right|^{3+}$ 이온의 용출}

전기응집을 수행하면 양극을 통해 알루미늄 이온 $\left(\mathrm{Al}^{3+}\right)$ 이 용출된다. Faraday 법칙을 이용하여 용출되는 이론적 $\mathrm{Al}^{3+}$ 의 양을 계산하여 황산알루미늄(alum)과 같은 응집제를 투여하 는 응집공정의 $\mathrm{Al}^{3+}$ 농도와 비교하여 보았다. 식 (5)를 이용하 여 전기응집에 의해 용출된 이론적 알루미늄 이온 $\left(\mathrm{Al}^{3+}\right)$ 의 질 
량을 계산한다.

$$
\mathrm{W}_{\text {theoretical }}=\frac{\mathrm{J} \cdot \mathrm{t} \cdot \mathrm{M}}{\mathrm{Z} \cdot \mathrm{F}}
$$

$\mathrm{W}_{\text {theoretical }}$ : mass of dissolved electrode material per electrode area $\left(\mathrm{g}_{\mathrm{Al}} / \mathrm{m}^{2}\right)$

$\mathrm{J}$ : current density $\left(\mathrm{A} / \mathrm{m}^{2}\right)$

$\mathrm{t}$ : contact time of electro-coagulation (s)

M: molar mass of aluminum $(26.98 \mathrm{~g} / \mathrm{mol})$

$\mathrm{z}$ : number of electrons transferred $(\mathrm{z}=3)$

F: Faraday's constant $(96,500 \mathrm{C} / \mathrm{mol})$

우선 전류밀도 $24 \mathrm{~A} / \mathrm{m}^{2}$ 조건에서 2시간 전기응집을 수행하 였을 경우 용출되는 $\mathrm{Al}^{3+}$ 의 질량은 다음 식 (6)과 같이 계산 된다.

$$
\begin{aligned}
\mathrm{W}_{\text {theoretical }}=\frac{24 \mathrm{~A}}{\mathrm{~m}^{2}} & \times \frac{7,200 \mathrm{~s}}{1} \times \frac{26.98 \mathrm{~g}}{\mathrm{~mol}} \times \frac{1}{3} \\
& \times \frac{\mathrm{mol}}{96,500 \mathrm{C}} \times \frac{1}{1 \mathrm{~A} \cdot \mathrm{s}} \\
= & 16.1 \mathrm{~g} / \mathrm{m}^{2}
\end{aligned}
$$

식 (7)을 이용하여 전류밀도 $24 \mathrm{~A} / \mathrm{m}^{2}, 2$ 시간 접촉시간 조건에 서 용출된 알루미늄의 단위 전극 면적당 질량을 계산하였다.

Theoretical mass of dissolved $\mathrm{Al}^{3+}(\mathrm{mg})$

$$
\begin{aligned}
& =\mathrm{W}_{\text {theoretical }}\left(\mathrm{g} / \mathrm{m}^{2}\right) \times \text { area of anode }\left(\mathrm{m}^{2}\right) \\
& =\frac{16.1 \mathrm{~g}}{\mathrm{~m}^{2}} \times 33.5 \mathrm{~cm}^{2} \times \frac{1,000 \mathrm{mg}}{1 \mathrm{~g}} \times\left(\frac{1 \mathrm{~m}}{100 \mathrm{~cm}}\right)^{2} \\
& =54 \mathrm{mg}
\end{aligned}
$$

전기응집 반응조의 부피가 $1 \mathrm{~L}$ 이므로 전류밀도 $24 \mathrm{~A} / \mathrm{m}^{2}$ 에 서 접촉시간 2 시간 동안 용출된 알루미늄의 농도는 $54 \mathrm{mg} / \mathrm{L}$ 이다. 전류밀도 $24 \mathrm{~A} / \mathrm{m}^{2}$ 조건에서 6시간과 12시간의 접촉시 간을 주었을 경우 용출되는 알루미늄의 이론적 농도를 같은 방법으로 계산하면 각각 $162 \mathrm{mg} / \mathrm{L}$ 과 $324 \mathrm{mg} / \mathrm{L}$ 이다. 또한, 전 류밀도 $2,2.5,6 \mathrm{~A} / \mathrm{m}^{2}$ 조건에서 용출된 알루미늄의 이론적 농도를 계산하여 Table3에 정리하였다. 그러나 전기응집조의 실제 $\mathrm{Al}^{3+}$ 농도는 Table3에서 계산된 이론적 $\mathrm{Al}^{3+}$ 농도보다 적을 것이다. 왜냐하면, $\mathrm{Al}$ 전극 표면은 활성슬러지 현탁액에 의한 생물막 오염이 필연적으로 발생하며, $\mathrm{Al}_{2} \mathrm{O}_{3}$ 와 같은 산화 피막과 생물막(bioflim) 등이 전극 표면에 생성되기 때문에 시 간이 경과할수록 용출되는 $\mathrm{Al}^{3+}$ 농도는 전기응집 초기에 반해 차츰 감소할 것이기 때문이다.

Table 3에서 계산된 결과를 바탕으로 황산알루미늄(alum) 을 응집제로 이용하여 $\mathrm{MBR}$ 의 막 오염을 저감한 연구결과와 본 연구처럼 전기응집을 통해 얻은 막 오염 저감 결과를 비교 해보았다. $\operatorname{Kim}$ 등(2006) ${ }^{28)}$ 은 황산알루미늄(alum)을 $5.5,11$,
Table 3. Calculated concentration of the dissolved $\mathrm{Al}^{3+}$ under different condition of electro-coagulation.

\begin{tabular}{cccccc}
\hline & \multicolumn{5}{c}{ Dissolved concentration of $\mathrm{A}^{3+}(\mathrm{mg} / \mathrm{L})$} \\
\cline { 2 - 5 } Contact time $(\mathrm{hr})$ & \multicolumn{5}{c}{ Current density $\left(\mathrm{A} / \mathrm{m}^{2}\right)$} \\
\cline { 2 - 5 } & 2.5 & 6 & 12 & 24 \\
\hline 2 & 6 & 14 & 27 & 54 \\
\hline 6 & 17 & 41 & 81 & 162 \\
\hline 12 & 34 & 81 & 162 & 324 \\
\hline
\end{tabular}

$22,44 \mathrm{mg} / \mathrm{L}$ 농도로 MBR에 주입하여 응집제를 주입하지 않 은 대조군에 비해 각각 $4.8,20,23.3,32.8 \%$ 의 막 오염이 감소 하였다고 보고하였다. 이들이 사용한 황산알루미늄의 농도 범 위, $5.5 \sim 44 \mathrm{mg} / \mathrm{L}$ 를 얻기 위한 조건을 Table 3에서 찾아보면 $2.5 \sim 24 \mathrm{~A} / \mathrm{m}^{2}$ 의 전류밀도로 $2 \sim 12$ 시간 전기응집을 수행하면 얻을 수 있다. 본 연구에서는 $2.5,6,12,24 \mathrm{~A} / \mathrm{m}^{2}$ 의 전류밀도 로 12 시간 전기응집하였을 때 대조군에 비해 각각 $15,24,34$, $86 \%$ 막 오염이 감소하였다.

황산알루미늄을 직접 응집제로 사용한 경우와 비교해서 큰 차이가 난다고 볼 수는 없지만, 전기응집의 전류밀도가 높은 경우라면 막 오염 감소 효과가 좀 더 큰 것으로 나타났다. 더 군다나 화학약품의 생산, 수송, 하적, 저장 및 사용과정에서 작업자의 안전 및 환경누출에 관한 규제가 지속적으로 강화되 고 있어서 화학약품의 사용에 관한 부정적인 면들을 고려하면 전기응집에 의한 막 오염 저감이 상대적인 강점을 갖는다고 볼 수 있다.

물론 응집제를 직접 투여하는 것과 전기응집을 통해 용출되 는 알루미늄의 양을 비교하는 것은 다소 무리가 있다. 왜냐하 면, 응집제로 투입되거나 전극에서 용출된 알루미늄은 가수분 해 과정을 거쳐서 $\mathrm{Al}(\mathrm{OH})_{2}{ }^{+}, \mathrm{Al}(\mathrm{OH})^{2+}, \mathrm{Al}(\mathrm{OH})_{4}{ }^{-}$등과 같은 알루미늄 수산화물로 변하기 때문이다. 전기응집 과정에서 이 런 배위화합물들의 화학적 거동이 잘 알려지지 않은 상태에서 응집제를 직접 투입하는 결과와 전기응집을 비교하는 것은 분명 한계가 존재한다. 더구나 막 오염 저감 정도를 비교하는 것은 사용한 막의 종류 및 $\mathrm{MBR}$ 운전형태, 활성슬러지의 생물 학적 특성 등이 모두 다른 상태이기 때문에 둘 사이의 비교는 유의할 필요가 있다.

\section{3. 전기응집으로 인한 활성슬러지의 특성 변화}

이상에서 전기응집 효과로 인해 활성슬러지 혼합액의 막 오 염이 감소하는 결과를 관찰하였다. $\mathrm{MBR}$ 공정에서 막 여과 특성에 영향을 주는 인자는 3 가지로 알려져 있다. ${ }^{29)}$ i) 분리막 의 특성(막 재질, 공극률, 세공 크기, 소수성 등), ii) 공정의 운전변수(HRT, SRT, f/m비 등), iii) 활성슬러지의 특성이다. 첫 번째와 두 번째 인자는 전기응집으로 인해 변화하는 것이 아니므로, 전기응집으로 인해 막 여과 성능이 향상된 것을 설 명하기 위해서는 당연히 활성슬러지 혼합액의 특성 변화에 
주목하여야 한다. 즉, 전기응집으로 인해 활성슬러지 혼합액 의 특성이 어떻게 변화하였는지 규명할 필요가 있다. 전기응 집을 수행하여 얻는 막 여과 성능의 증가 원인을 설명하기 위해 활성슬러지 혼합액 구성성분들의 변화 중 $\mathrm{EPS}$, 용존성 $-\mathrm{COD}$, 용존성-TN, 용존성-TP 성분의 변화를 관찰하였다.

\subsection{1. 세포 외 고분자 물질(EPS)}

미생물 세포가 분비하는 $\mathrm{EPS}$ 는 MBR 공정의 막 오염을 유 발하는 중요한 물질로 오래 전부터 지목되어 왔다. ${ }^{30)} \mathrm{EPS}$ 는 겔(gel)과 같은 고수화물 형태로 이루어져 있으며 접착력이 높아서 막의 기공에 쉽게 흡착되어 세공이 좁아지거나 막히게 하여 막 오염을 심화시키기 때문에 막 오염의 주요한 원인물 질로 알려져 있다. EPS는 활성슬러지 혼합액 내에 용존성으 로 존재하는 soluble-EPS와 활성슬러지 플록(flocs) 내부에 존 재하며 세포와 세포를 연결해주는 역할을 하는 bound-EPS로 구분된다. 특히, bound-EPS는 활성슬러지 플록 내부에 존재 하기 때문에 분리막 표면의 케이크 층에 쌓이게 되면서 여과 수의 흐름을 방해하는 메커니즘으로 막 오염을 유발하는 것으 로 알려져 있다. ${ }^{31,32)}$ 따라서 전기응집이 EPS에 미치는 영향을 알아보기 위해 soluble-EPS와 bound-EPS를 각각 분석하였다.

Fig.4와 Fig.5는 MLSS 농도가 서로 다른 활성슬러지 혼합액 을 전류밀도를 변화하면서 12 시간 동안 전기응집을 수행한

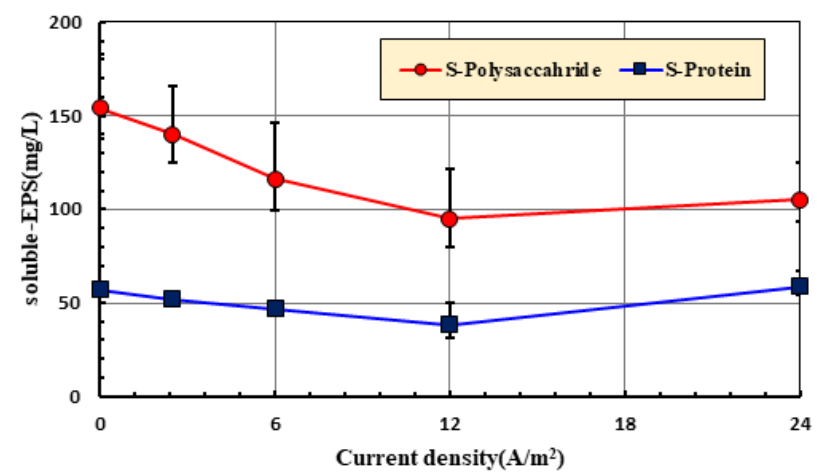

Fig. 4. Variation in soluble-EPS concentration as function of current density (MLSS= 3,950 8,500 mg/L).

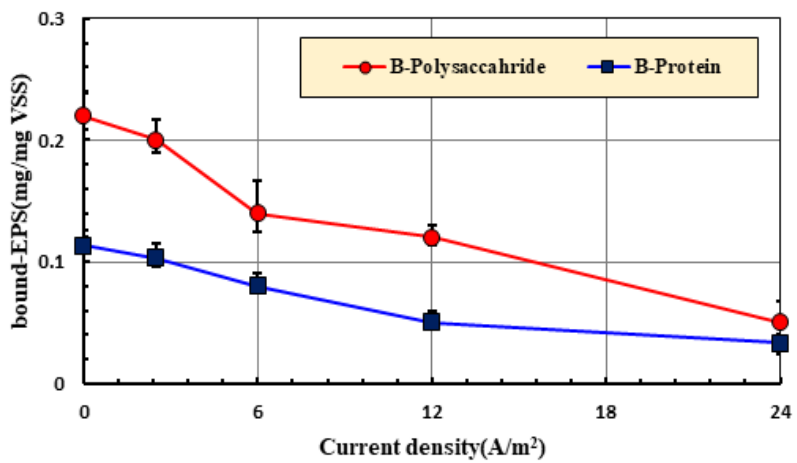

Fig. 5. Variation in bound-EPS concentration as function of current density (MLSS= 3,950 8,500 mg/L).
후 EPS의 주성분인 단백질과 다당류를 분석한 결과이다.

전류밀도가 2.5 에서 $12 \mathrm{~A} / \mathrm{m}^{2}$ 로 증가하면 soluble-EPS는 감 소하다가, 전류밀도 $24 \mathrm{~A} / \mathrm{m}^{2}$ 에서는 약간 증가하는 경향을 보 인다. 그러나 bound-EPS는 전류밀도가 증가할수록 일관되게 감소하였다. 즉, 전기응집 효과가 증가할수록 막 오염을 유발 하는 bound-EPS의 농도가 감소하는 것으로 해석된다.

전기응집으로 인해 soluble-EPS의 주성분인 단백질과 다당 류의 농도 감소 폭은 큰 차이를 보였다. 다당류 성분은 전류밀 도 $12 \mathrm{~A} / \mathrm{m}^{2}$ 에서 $38 \%$ 감소하였다가 전류밀도가 $24 \mathrm{~A} / \mathrm{m}^{2}$ 로 증가하면 $32 \%$ 감소율을 보였다. 이는 과도한 전류가 흐른 24 $\mathrm{A} / \mathrm{m}^{2}$ 조건일 때 활성슬러지 플록의 해체(disintegration) 현상 이 발생하여 플록 내부의 EPS 성분이 모용액으로 상당 부분 용출된 것이 원인으로 추정된다. 그러나 단백질 성분은 전류 밀도가 $24 \mathrm{~A} / \mathrm{m}^{2}$ 로 증가하여도 농도에 큰 변화를 보이지 않았 다. Ibeid 등(2015) $)^{33)}$ 이 전류밀도의 세기가 $15 \sim 35 \mathrm{~A} / \mathrm{m}^{2}$ 일 때 soluble-EPS 중 단백질 성분은 $50 \%$, 다당류 성분은 $90 \%$ 까지 제거하였다고 보고한 결과를 보면 단백질 성분보다는 다당류 성분이 전기응집에 민감하게 반응하는 것을 간접적으로 확인 할 수 있다. 물론 활성슬러지의 MLSS 농도 및 SRT와 같은 미생물 특성과 전기응집 시간 및 조건 등이 모두 다르므로 다른 연구와의 직접 비교는 제한적 범위에서만 가능하다.

활성슬러지 모 용액(bulk solution)에 존재하는 soluble-EPS 는 응집과정에서 생성되는 $\mathrm{Al}(\mathrm{OH})_{3}$ 와 같은 불용성 염에 부착 되어 제거되는 체 거름(sweep floc) 메커니즘에 의해 감소한 것으로 해석된다. 반면, bound-EPS는 전류밀도가 증가할수록 그 농도가 감소하였는데, 이는 플록 내부의 bound-EPS가 플 록 외부로 탈리되었기 때문으로 보인다. 즉, 반응기 내부에 흐르는 전류가 물을 포함한 겔 형태 $\mathrm{EPS}$ 의 주변 환경을 변화 시켜서 미생물 플록 내부(또는 표면)에 존재하는 bound-EPS 들의 탈착을 유도한 것으로 해석된다. 특히, 전류밀도가 24 $\mathrm{A} / \mathrm{m}^{2}$ 와 같이 높은 경우에는 활성슬러지 플록이 상당 부분 해 체되어 내부의 bound-EPS 농도가 급격히 낮아졌으며, 이로 인해 막 오염이 상당 부분 감소한 원인 중 하나로 작용하였음 을 시사하고 있다. Lee 등 $(2011)^{34)}$ 도 활성슬러지에 전류를 흘 려 슬러지를 가용화시키는 연구에서 슬러지 플록이 해체되는 연구결과를 보고하였다. 플록이 해체되면 플록 내부에 존재하 는 bound-EPS가 플록 외부로 탈리되기 때문에 본 연구에서처 럼 bound-EPS 농도의 감소로 나타난 것이다.

결과적으로 모 용액에 존재하는 콜로이드성 물질과 탈리 된 EPS 및 불용성염인 $\mathrm{Al}(\mathrm{OH})_{3}$ 등이 서로 반응하여 플록의 질량을 증가시키는 현상을 유도한 것으로 판단된다. 이는 다음 절에서 설명할 MLSS가 증가하게 되는 원인으로 작용 한다. 또한, 전기응집 과정에서 발생 가능한 화학적 산화에 의해 플록 내부에 존재하는 EPS가 생분해 가능한 유기물로 전환되었을 것으로 추정하는 Hua 등 $(2015)^{26)}$ 의 연구처럼 $\mathrm{EPS}$ 가 플록 내부에서 산화 되거나 중간 화합물로 변환되어서 
bound-EPS 농도가 감소하는 원인으로 작용하였을 가능성도 배제할 수 없다.

\subsubsection{MLSS와 MLVSS}

전기응집이 활성슬러지 혼합액의 MLSS와 MLVSS에 미치 는 영향을 Fig.6에 제시하였다. 활성슬러지 혼합액의 초기 MLSS가 3,950 mg/L인 경우, 12 시간 동안 $24 \mathrm{~A} / \mathrm{m}^{2}$ 의 전류밀 도를 인가하면 $4,700 \mathrm{mg} / \mathrm{L}$ 까지 증가하여, $19 \%$ 의 MLSS 증가 를 가져왔다. 전류밀도가 $12 \mathrm{~A} / \mathrm{m}^{2}$ 인 경우는 $16 \%, 6 \mathrm{~A} / \mathrm{m}^{2}$ 인 경우는 $6 \%$ 증가하였고, $2.5 \mathrm{~A} / \mathrm{m}^{2}$ 로 낮아지면 $4 \%$ 만이 증가하 였다. MLSS 초기농도가 $6,200 \mathrm{mg} / \mathrm{L}$ 일 경우에도 전류밀도에 따라 2 6\% 정도만 증가하였다.

MLSS 농도가 $8,150 \mathrm{mg} / \mathrm{L}$ 일 때 전류밀도가 $24 \mathrm{~A} / \mathrm{m}^{2}$ 일 경우 에는 $3 \%$ 증가하였고, 전류밀도가 $12,6,2.5 \mathrm{~A} / \mathrm{m}^{2}$ 일 때는 $2 \%$ 미만으로 거의 증가하지 않았다. 즉, 활성슬러지의 초기 MLSS 농도가 작을수록 전류밀도의 영향을 크게 받으며, 전류밀도가 증가할수록 MLSS 증가 폭이 더욱 큰 것으로 나타났다.

그러나 MLVSS는 전체적으로 큰 변화가 없었다. 즉, 12 시간 의 짧은 전기응집 시간으로 인해 현탁 성분 중 미생물 성분을 대변하는 MLVSS는 MLSS에 비해 상대적으로 적게 증가하였 다. 따라서 증가한 MLSS는 무기물 성분 증가에 의한 것으로 설명될 수 있다.

전기응집 과정에서는 다음 식 (8), (9)와 같이 $\mathrm{Al}(\mathrm{OH})_{3}$ 와 $\mathrm{AlPO}_{4}$ 와 같은 불용성 염이 생성되는 것으로 알려져 있다. ${ }^{35)}$ 전기응집으로 인해 양극에서 유리된 알루미늄 이온 $\left(\mathrm{Al}^{3+}\right)$ 이 수중의 알칼리도와 반응하여 생기는 불용성 수산화알루미늄, $\mathrm{Al}(\mathrm{OH})_{3}$ 과 혼합액 중의 인산염 $\left(\mathrm{PO}_{4}{ }^{3-}\right)$ 과 반응하여 생기는 불 용성 인산알루미늄, $\mathrm{AlPO}_{4}$ 에 의해 MLSS 농도가 증가한 것 이다.

$$
\begin{aligned}
& \mathrm{Al}^{3+}+3 \mathrm{H}_{2} \mathrm{O} \rightarrow \mathrm{Al}(\mathrm{OH})_{3}+3 \mathrm{H}^{+} \\
& \mathrm{Al}^{3+}+\mathrm{PO}_{4}^{-3} \rightarrow \mathrm{AlPO}_{4}
\end{aligned}
$$

식 (8)과 (9)의 $\mathrm{K}_{\mathrm{sp}}$ 값은 $3 \times 10^{-34}$ 과 $9.8 \times 10^{-21}$ 로 매우 작아서 불용성 염으로 간주할 수 있다. 즉, 전체 부유물질, MLSS 농

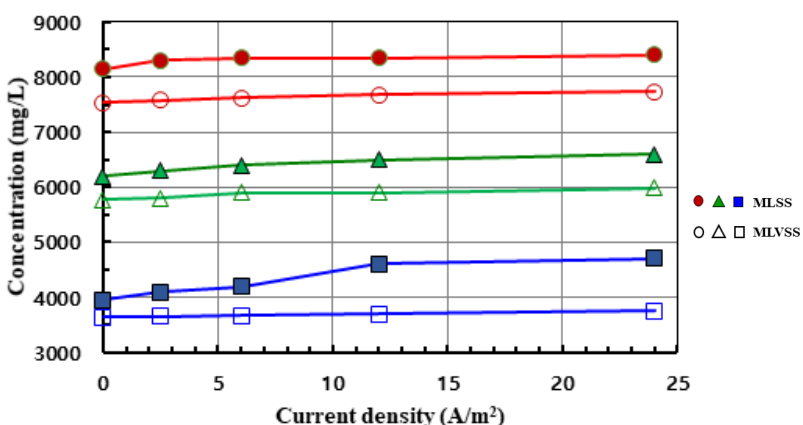

Fig. 6. Variation of MLSS and MLVSS concentration as a function of current density.
도는 생성된 무기성 불용성염, $\mathrm{Al}(\mathrm{OH})_{3}$ 와 $\mathrm{AlPO}_{4}$ 에 의해 증가 하였지만, 유기물 성분을 대표하는 MLVSS는 큰 변화가 없었 던 것이다.

일반적으로 MLSS가 증가하면 분리막 표면에 케이크 층이 축적되는 요인으로 작용하여 막 오염이 증가한다. 그러나 전 기응집으로 인해 MLSS가 약간 증가했음에도 불구하고 막 오 염이 증가하는 효과로 작용하지 않았다. 오히려 $\mathrm{Al}(\mathrm{OH})_{3}$ 와 $\mathrm{AlPO}_{4}$ 와 같은 불용성 무기염의 생성이 막 표면의 케이크 층 을 쓸어버리는 효과(scouring effect)로 작용하여 막 오염은 오 히려 감소한 것으로 나타났다. 또한 $\mathrm{Al}(\mathrm{OH})_{3}$ 와 $\mathrm{AlPO}_{4}$ 와 같은 불용성 무기염이 막 표면에서 동적 막(dynamic membrane) 역 할을 하여 막 오염이 완화된 것으로 설명할 수 있다. ${ }^{36}$ 전기응 집 이후에 생성되는 불용성 염이 분리막 표면에 침착되어 분 리막 표면에 막 오염물질들이 직접 쌓이는 것을 방지하는 역 할, 즉 동적 막의 기능을 하였기 때문에 막 오염이 감소한 것 으로 설명할 수 있다.

동적 막의 발생에 대한 근거를 제시하기 위해 전기응집으로 생성되는 $\mathrm{AlPO}_{4}$ 및 $\mathrm{Al}(\mathrm{OH})_{3}$ 발생량을 계산하여 보았다. 다음 식 (10) (13)의 과정을 통해 생성된 알루미늄 몰수와 발생 $\mathrm{AlPO}_{4}$ 및 $\mathrm{Al}(\mathrm{OH})_{3}$ 의 질량을 계산하였다. 우선 전류밀도 24 $\mathrm{A} / \mathrm{m}^{2}$ 조건에서 12 시간 전기응집하였을 때 발생하는 알루미늄 몰수를 식 (10)을 통해 계산한다. 이때 용출된 $\mathrm{Al}^{3+}$ 의 질량은

Table 3에 이미 계산된 값, $324 \mathrm{mg}$ 을 이용하면 된다.

mol of dissolved $\mathrm{Al}^{3+}$

$$
\begin{aligned}
& =\frac{\text { mass of dissolved } \mathrm{Al}^{3+}}{\mathrm{mol} \mathrm{of} \mathrm{Al}^{3+}} \\
& =\frac{324 \mathrm{mg}}{1} \times \frac{\mathrm{mol}}{26.98 \mathrm{~g}} \times \frac{1 \mathrm{~g}}{1,000 \mathrm{mg}}=0.012 \mathrm{~mol}
\end{aligned}
$$

발생하는 $\mathrm{AlPO}_{4}$ 의 질량은 식 (11)을 이용하여 계산한다. 식 (9)에서처럼 $\mathrm{Al}^{3+}$ 와 $\mathrm{AlPO}_{4}$ 의 몰 비는 1:1이므로 $\mathrm{AlPO}_{4}$ 의 질량 은 식 (10)과 같이 계산된다.

mass of produced $\mathrm{AlPO}_{4}$

$=\mathrm{M} . \mathrm{W}$ of $\mathrm{AlPO}_{4} \times \mathrm{mol}$ of dissolved $\mathrm{Al}^{3+}$

$$
\begin{aligned}
& =\frac{121.95 \mathrm{~g}}{\mathrm{~mol}} \times \frac{0.012 \mathrm{~mol}}{1} \times \frac{1,000 \mathrm{mg}}{1 \mathrm{~g}} \\
& =1,463 \mathrm{mg}
\end{aligned}
$$

그러나 활성슬러지 현탁액의 초기 용존성 $\mathrm{TP}$ 농도는 약 2 $\mathrm{mg} / \mathrm{L}\left(=0.02 \mathrm{mmol} \mathrm{PO}_{4}{ }^{3-} / \mathrm{L}\right)$ 정도(Fig.8 참조)로 매우 작음을 감안하면, 식 (11)에서 계산된 $\mathrm{AlPO}_{4}$ 질량은 식 (12)처럼 2.4 $\mathrm{mg}$ 으로 수정되어야 한다.

mass of produced $\mathrm{AlPO}_{4}$

$=\mathrm{M} . \mathrm{W}$ of $\mathrm{AlPO}_{4} \times \mathrm{mol}$ of dissolved $\mathrm{PO}_{4}{ }^{3-}$

$$
=\frac{121.95 \mathrm{~g}}{\mathrm{~mol}} \times \frac{0.012 \times 10^{-3} \mathrm{~mol}}{1} \times \frac{1,000 \mathrm{mg}}{1 \mathrm{~g}}=2.4 \mathrm{mg}
$$


한편, 동일한 전기응집 조건에서 생성된 $\mathrm{Al}(\mathrm{OH})_{3}$ 의 질량을 계 산하면 다음과 같다.

mass of produced $\mathrm{Al}(\mathrm{OH})_{3}$

$$
\begin{aligned}
& =\mathrm{M} \cdot \mathrm{W} \text { of } \mathrm{Al}(\mathrm{OH})_{3} \times \mathrm{mol} \text { of dissolved } \mathrm{Al}^{3+} \\
& =\frac{78 \mathrm{~g}}{\mathrm{~mol}} \times \frac{0.012 \mathrm{~mol}}{1} \times \frac{1,000 \mathrm{mg}}{1 \mathrm{~g}} \\
& =936 \mathrm{mg}
\end{aligned}
$$

식 (13)에서 계산된 $\mathrm{Al}(\mathrm{OH})_{3}$ 의 질량은 $\mathrm{AlPO}_{4}$ 생성에 사용 된 $\mathrm{Al}^{3+}$ 의 질량을 감해주지 않고 계산한 것이다. 즉, 용출된 $\mathrm{Al}^{3+}$ 의 일부는 $\mathrm{AlPO}_{4}$ 생성에 이미 사용되었으므로, 식 (12)에 서 그만큼 $\mathrm{Al}^{3+}$ 의 질량을 빼주고 계산하여야 한다. 결국, 식 (13)에서 계산된 $\mathrm{Al}(\mathrm{OH})_{3}$ 의 농도는 $936 \mathrm{mg}$ 보다는 적을 것이 다. 그러나 식 (12)에서 보듯이 그 값이 매우 적으므로 936 $\mathrm{mg}$ 으로 간주해도 무방하다. 따라서 전류밀도 $24 \mathrm{~A} / \mathrm{m}^{2}$ 조건에 서 12 시간 전기응집하였을 때 발생하는 무기성 침전물의 이 론적 총 질량은 $2.4+936=938.4 \cong 938 \mathrm{mg}$ 정도이다. 전기 응집 반응조의 부피가 $1 \mathrm{~L}$ 이므로 생성된 무기성 침전물의 이 론적 농도는 $938 \mathrm{mg} / \mathrm{L}$ 이다.

전기응집을 수행하지 않은 대조군과 전류밀도 $24 \mathrm{~A} / \mathrm{m}^{2}$ 의 조건에서 12 시간 전기응집한 후의 무기현탁고형물, FSS (fixed suspended solids, FSS = MLSS-MLVSS)를 계산하여 Table 4에 정리하였다.

전기응집 수행 이전에는 무기물 성분인 FSS 농도가 316 , $433,611 \mathrm{mg} / \mathrm{L}$ 이었으나 전기응집 이후에는 각각 948,613 , $665 \mathrm{mg} / \mathrm{L}$ 로 증가하였다. 초기 MLSS 농도가 $3,950 \mathrm{mg} / \mathrm{L}$ 의 경우에 증가한 $\mathrm{FSS}$ 는 $632 \mathrm{mg} / \mathrm{L}(=948-316 \mathrm{mg} / \mathrm{L})$ 이다. 초기 MLSS 농도가 6,200과 $8,150 \mathrm{mg} / \mathrm{L}$ 에서도 FSS 증가분은 각각 $180 \mathrm{mg} / \mathrm{L}$ 와 $54 \mathrm{mg} / \mathrm{L}$ 이었다. 이론적 계산치인 $938 \mathrm{mg} / \mathrm{L}$ 에는 못 미치지만, 앞에서 설명한 이론적 계산치가 갖는 여러 가지 한계점 및 실험 오차 등을 감안한다면 전기응집으로 인해 발 생한 MLSS 증가 현상은 주로 무기물 성분인 FSS 증가로 인 한 것이라고 설명할 수 있다.

전기응집으로 용출된 $\mathrm{Al}^{3+}$ 이 $\mathrm{Al}(\mathrm{OH})_{3}$ 로 충분히 석출될 수 있는 조건인지 확인하기 위하여 Fig. ${ }^{37}$ 과 같은 $\mathrm{pC}-\mathrm{pH}$ 다이

Table 4. Summary of the solids concentration before and after the electro-coagulation with $24 \mathrm{~A} / \mathrm{m}^{2}$ for 12 hrs.

\begin{tabular}{cccc} 
& \multicolumn{3}{c}{ Solids concentration (mg/L) } \\
\cline { 2 - 4 } & MLSS & MLVSS & FSS (=MLSS-MLVSS) \\
$\begin{array}{c}\text { Before } \\
\text { electro-coagulation }\end{array}$ & 3,950 & 3,634 & 316 \\
\cline { 2 - 4 } & 6,200 & 5,767 & 433 \\
\cline { 2 - 4 } After & 8,150 & 7,539 & 611 \\
\hline electro-coagulation & 4,700 & 3,752 & 948 \\
\cline { 2 - 4 } & 6,600 & 5,987 & 613 \\
\hline & 8,400 & 7,735 & 665 \\
\hline
\end{tabular}

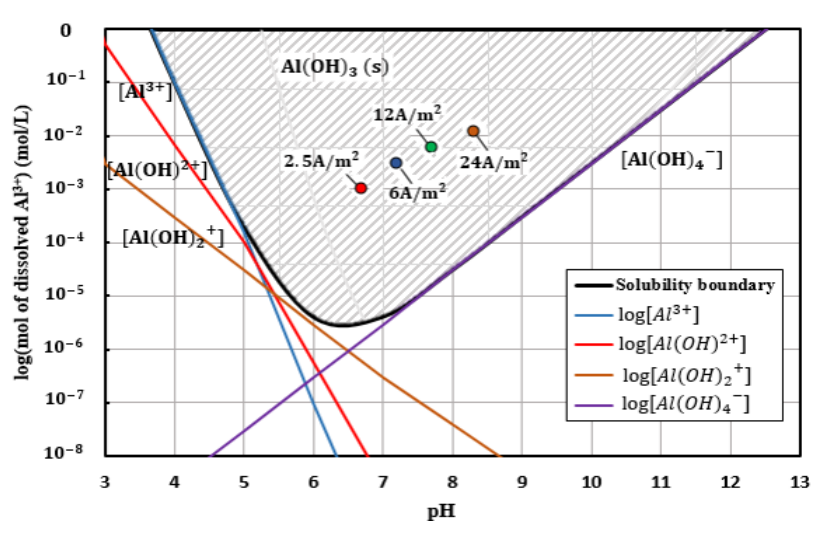

Fig. 7. Solubility diagram of aluminum hydroxide and the concentration profile of $\mathrm{Al}^{3+}$ dissolved by electrocoagulation under different condition of current density.

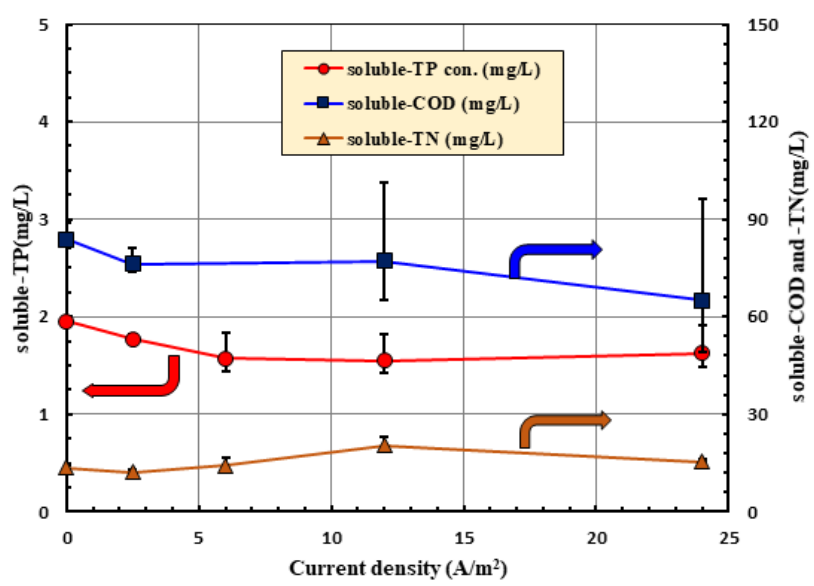

Fig. 8. Variation of soluble-COD, -TN, -TP concentration as a function of current density.

어그램을 활용하였다. 전류밀도 $24 \mathrm{~A} / \mathrm{m}^{2}$ 조건에서 12 시간 전 기응집하였을 때 용출되는 $\mathrm{Al}^{3+}$ 의 총 농도(total concentration), $\mathrm{C}_{\mathrm{T}}$ 는 식 (10)에서 계산하였듯이 $0.012 \mathrm{~mol} / \mathrm{L}$ 이다. 전기응집 실험의 $\mathrm{pH}$ 는 약 8.3 이었으므로 Fig.7에 $\mathrm{C}_{\mathrm{T}}$ 와 $\mathrm{pH}$ 에 해당하는 지점을 표시하였다. 그래프의 빗금 안쪽이 $\mathrm{Al}(\mathrm{OH})_{3}$ 로 침전되 는 조건이므로 본 연구에서 수행된 전기응집 조건에서 용출된 $\mathrm{Al}^{3+}$ 은 모두 $\mathrm{Al}(\mathrm{OH})_{3}$ 로 석출될 수 있는 조건임을 확인할 수 있다. 마찬가지 방법으로 전류밀도가 다른 조건 즉, $2.5,6$, $12 \mathrm{~A} / \mathrm{m}^{2}$ 조건에서의 $\mathrm{Al}^{3+}$ 의 총 농도를 계산하고 Fig.7에 표시 하였다. 그림에서 보듯이 모두 빗금이 있는 부분의 안쪽에 존 재하므로 $\mathrm{Al}(\mathrm{OH})_{3}$ 로 석출될 수 있는 조건임을 확인하였다.

\subsubsection{Soluble-COD, -TN, -TP}

일련의 전기응집 수행 후 soluble-COD, soluble-TN, soluble$\mathrm{TP}$ 의 농도 변화를 관찰하였다(Fig. 8). Soluble-COD는 초기농 도 $83 \mathrm{mg} / \mathrm{L}$ 에서 전류밀도 $24 \mathrm{~A} / \mathrm{m}^{2}$ 를 12시간 인가하였을 경우 $65 \mathrm{mg} / \mathrm{L}$ 로 약 $23 \%$ 감소하였다. 이는 $\mathrm{Al}(\mathrm{OH})_{3}$ 와 같은 불용성 염이 생성되는 과정에서 체 거름 현상으로 인해 유기물 성분 
이 응집되어 제거된 것으로 보인다. Lacasa 등 $(2011)^{38)}$ 은 전기 응집의 전류 자극이 미생물의 활성화를 촉진하여 유기물질 제거 효율이 높아진다고 보고하였는데 이런 요인도 작용한 것으로 보인다. 한편, soluble-TN, -TP의 농도는 전류밀도의 세기가 증가할수록 악간 감소하거나 증가하는 경향을 보였 으나, 오차범위 내에서 유의미한 변화가 있다고 보기는 어려 웠다.

\section{4. 결론}

전기응집 공정의 중요 운전 인자인 전류밀도와 접촉시간의 변화가 막 오염에 미치는 영향을 파악하고, 감소한 막 오염 현상을 설명하기 위해 활성슬러지의 특성 변화를 관찰하여 다음과 같은 결론을 도출하였다.

1) 전기응집 공정의 중요한 운전 변수인 전류밀도와 접촉시 간이 증가할수록 총오염저항 $\left(\mathrm{R}_{\mathrm{c}}+\mathrm{R}_{\mathrm{f}}\right)$ 은 감소하였다. 전기응집 이 MLSS로 대표되는 입자성 물질보다는 용존성 막 오염 물 질의 제거 기작에 의해 효과적으로 작용하여 막 오염이 감소 한 것으로 나타났다.

2) 전류밀도가 증가할수록 soluble-EPS, bound-EPS 및 soluble-COD의 농도가 감소하는 경향을 보였다. Soluble-EPS 와 soluble-COD가 감소한 것은 응집과정에서 발생하는 불용 성 무기염에 용존 성분이 응집되어 감소하였고, 활성슬러지 플록 내부의 bound-EPS는 반응기 내부에 흐르는 전류로 인해 플록 외부로 탈리되어 감소한 것으로 추측된다.

3) 그러나 전류밀도가 $24 \mathrm{~A} / \mathrm{m}^{2}$ 처럼 높은 경우에는 soluble$\mathrm{EPS}$ 가 약간 증가하는 경향을 보였다. 전류밀도가 높으면 미 생물에 과도한 전기적 자극이 발생하며 미생물 활성도에 악영 향을 미치게 되며 이로 인해 플록이 해체되는 현상이 발생하 여 soluble-EPS가 증가한 것으로 판단된다.

4) 전류밀도가 증가할수록 MLSS 농도가 증가하였지만 MLVSS는 변화가 거의 없었다. 즉, 응집과정에서 발생하는 무기염, $\mathrm{Al}(\mathrm{OH})_{3}$ 과 $\mathrm{AlPO}_{4}$ 에 의해 무기성 고형물 성분이 증가 하려 MLSS가 증가하였으며, 이렇게 생성되는 불용성 무기물 이 용존성 막 오염 물질의 체 거름 작용 또는 동적 막 역할을 하여 막 오염 감소의 주요 원인으로 작용하였다.

\section{Acknowledgement}

본 연구는 한국연구재단의 연구비 지원으로 수행되었습니 다. 이에 감사드립니다(과제번호: 2019R1F1A1042061).

\section{References}

1. F. Meng, S. R. Chae, A. Drews, M. Kraume, H. S. Shin, F. Yang, Recent advances in membrane bioreactors (MBRs): membrane fouling and membrane material, Water Res.,
43(6), 1489-1512(2009).

2. W. Yang, N. Cicek, J. Ilg, State-of-the-art of membrane bioreactors: worldwide research and commercial applications in North America, J. Membrane Sci., 270(1-2), 201-211(2006).

3. Z. Wang, Z. Wu, S. Mai, C. Yang, X. Wang, Y. An, Z. Zhou, Research and applications of membrane bioreactors in China: progress and prospect, Sep. Purif. Technol., 62(2), 249-263(2008).

4. J. Wu, P. Le-Clech, R. M. Stuetz, A. G. Fane, V. Chen, Effects of relaxation and backwashing conditions on fouling in membrane bioreactor, J. Membrane Sci., 324(1-2), 26-32(2008).

5. B. R. Lim, K. H. Ahn, K. G. Song, J. W. Cho, Microbial community in biofilm on membrane surface of submerged MBR: effect of in-line cleaning chemical agent, Water Sci. Technol., 51(6-7), 201-207(2005).

6. P. Le-Clech, V. Chen, T. A. G. Fane, Fouling in membrane bioreactors used in wastewater treatment, J. Membrane Sci., 284(1-2), 17-53(2006).

7. K. M. Yeon, W. S. Cheong, H. S. Oh, W. N. Lee, B. K. Hwang, C. H. Lee, H. Beyenal, Z. Lewandowski, Q. Sensing, A new biofouling control paradigm in a membrane bioreactor for advanced wastewater treatment, Environ. Sci. Technol., 43(2), 380-385(2009).

8. M. F. Siddiqui, M. Rzechowicz, W. Harvey, A. W. Zularisam, G. F. Anthony, Quorum sensing based membrane biofouling control for water treatment: a review, J. Water Process. Eng., 7, 112-122(2015).

9. I. D. Kampouris, P. D. Karayannakids, D. C. Banti, D. Sakoula, D. Konstantinidis, M. Yiangou, P. E. Samaras, Evaluation of a novel quorum quenching strain for MBR biofouling mitigation, Water Res., 143, 56-65(2018).

10. R. Niazmand, M. Jahani, F. Sabbagh, S. Rezania, Optimization of electrocoagulation conditions for the purification of table olive debittering wastewater using response surface methodology, Water, 12(6), 1687-1704(2020).

11. S. R. Tchamango, K. W. Ngayo, P. D. B. Belibi, F. Nikouam, M. B. Ngassoum, Treatment of a dairy effluent by classical electrocoagulation and indirect electrocoagulation with aluminum electrodes, Sep. Sci. Technol., 55(6), 1128-1139 (2020).

12. A. Shahedi, A. K. Darban, F. Taghipour, A. Jamshidi-Zanjani, A review on industrial wastewater treatment via electrocoagulation processes, Curr. Opin. Electrochem., 22, 154-169(2020).

13. A. D. Tafti, S. M. S. Mirzaii, M. R. Andalibi, M. Vossoughi, Optimized coupling of an intermittent DC electric field with a membrane bioreactor for enhanced effluent quality and hindered membrane fouling, Sep. Purif. Technol., 152, 7-13(2015).

14. K. Sadeddin, A. Naser, A. Firas, Removal of turbidity and suspended solids by electro-coagulation to improve feed water quality of reverse osmosis plant, Desalination, 268(1-3), 204-207(2011).

15. L. Liu, J. Liu, B. Gao, F. Yang, Minute electric field reduced 
membrane fouling and improved performance of membrane bioreactor, Sep. Purif. Technol., 86, 106-112(2012).

16. B. Zhu, D. A. Clifford, S. Chellam, Comparison of electrocoagulation and chemical coagulation pretreatment for enhanced virus removal using microfiltration membranes, Water Res., 39(13), 3098-3108(2005).

17. K. Bani-Melhem, M. Elektorowicz, Development of a novel submerged membrane electro-bioreactor (SMEBR): performance for fouling reduction, Environ. Sci. Technol., 44(9), 3298-3304(2010).

18. M. Ben-Sasson, Y. M. Lin, A. Adin, Electrocoagulationmembrane filtration hybrid system for colloidal fouling mitigation of secondary-effluent, Sep. Purif. Technol., 82, 63-70(2011).

19. K. B. Melhem, M. Elektorowicz, Performance of the submerged membrane electro-bioreactor (SMEBR) with iron electrodes for wastewater treatment and fouling reduction, $\mathrm{J}$. Membrane Sci., 379(1-2), 434-439(2011).

20. K. Bani-Melhme, E. Smith, Grey water treatment by a continuous process of an electrocoagulation unit and a submerged membrane bioreactor system, J. Chem. Eng., 198-199, 201-210(2012).

21. American Public Health Association, American Water Works Association, Water Environment Federation, Standard Methods for examination of water and wastewater, 19th ed., American Public Health Association, Washington, USA, pp. 53-58(1995).

22. Z. Wang, Z. Wu, S. Tang, Extracellular polymeric substances (EPS) properties and their effects on membrane fouling in a submerged membrane bioreactor, Water Res., 43(9), 2504-2512(2009).

23. O. H. Lowry, N. J. Rosebrough, A. L. Farr, R. J. Randall, Protein measurement with the folin phenol reagent, J. Biol. Chem., 193(1), 265-275(1951).

24. D. B. Michel, K. A. Gilles, J. K. Hamilton, P. A. Rebers, F. Smith, Colorimetric method for determination of sugars and related substances, Anal. Chem., 28(3), 350-356(1956).

25. S. H. Han, I. S. Chang, Comparison of the cake layer removal options during determination of cake layer resistance $(\mathrm{Rc})$ in the resistance-in-series model, Sep. Sci. Technol., 49(16), 2459-2464(2014).

26. L. C. Hua, C. Huang, Y. C. Su, T. N. P. Nguyen, P. C. Chen, Effects of electro-coagulation on fouling mitigation and sludge characteristics in coagulation-assisted membrane bioreactor, J. Membrane Sci., 495, 29-36(2015).

27. J. Liu, L. Liu, B. Gao, F. Yang, Cathode membrane fouling reduction and sludge property in membrane bioreactor integrating electrocoagulation and electrostatic repulsion, Sep. Purif. Technol., 100, 44-50(2012).

28. K. Y. Kim, J. H. Kim, Y. H. Kim, H. S. Kim, The effect of coagulant on filtration performance in submerged MBR system, J. Korea Membrane Soc., 16(3), 182-187(2006).

29. I. S. Chang, P. L. Clech, B. Jefferson, S. Judd, Membrane fouling in membrane bioreactors for wastewater treatment, J. Environ. Eng., 128(11), 1018-1029(2002).

30. I. S. Chang, C. H. Lee, Membrane filtration characteristics in membrane coupled activated sludge system-the effect of physiological states of activated sludge on membrane fouling, Desalination, 120(3), 221-233(1998).

31. J. Zhang, H. C. Chua, J. Zhou, A. G. Fane, Factors affecting the membrane performance in submerged membrane bioreactors, J. Membrane Sci., 284(1-2), 54-66(2006).

32. H. Lin, M. Zhang, F. Wang, F. Meng, B. Q. Liao, H. Hong, J. Chen, W. Gao, A critical review of extracellular polymeric substances (EPSs) in membrane bioreactors: characteristics, roles in membrane fouling and control strategies, J. Membrane Sci., 460, 110-125(2014).

33. S. Ibeid, M. Elektorowicz, J. A. Oleszkiewicz, Electro-conditioning of activated sludge in a membrane electro-bioreactor for improved dewatering and reduced membrane fouling, J. Membrane Sci., 494, 136-142(2015).

34. J. S. Lee, I. S. Chang, C. K. Lee, S. Y. Joung, Study on solubilization of sewage sludge using electrolysis techniques, J. Korea Acad. Industr. Coop. Soc., 12(2), 979-984(2011).

35. W. K. Kim, S. J. Hong, I. S. Chang, Membrane fouling reduction using electro-coagulation aided membrane bio-reactor, J. Korea Acad. Industr. Coop. Soc., 19(8), 105-114(2018).

36. S. J. Hong, I. S. Chang, Effect of operating condition of electro-coagulation on the membrane filtration resistances of activated sludge, J. Korea Acad. Industr. Coop. Soc., 16(3), 2314-2320(2015).

37. K. Bensadok, S. Benammar, F. Lapicque, G. Nezzal, Electrocoagulation of cutting oil emulsions using aluminium plate electrodes, J. Hazard. Mater., 152(21), 423-430(2008).

38. E. Lacasa, P. Cañizares, C. Sáez, F. J. Fernández, M. A. Rodrigo, Electrochemical phosphates removal using iron and aluminium electrodes, J. Chem. Eng., 172(1), 137-143(2011).

\section{Declaration of Competing Interest}

The authors declare that they have no known competing financial interests or personal relationships that could have appeared to influence the work reported in this paper.

\section{Authors and Contribution Statement}

\section{Kyeong-Rae Kim}

Department of Environmental Engineering, Hoseo University, Master candidate, ORCID (D) 0000-0001-5374-6373: Methodology, Validation, Writing - original draft.

\section{In-Soung Chang}

Department of Environmental Engineering, Hoseo University, Professor, ORCID (1) 0000-0003-1230-416X: Conceptualization, Methodology, Validation, Writing - review and editing. 